ENCYCLOPEEDIE Encyclopédie berbère

BERBERE

$24 \mid 2001$

24 | Ida - Issamadanen

\title{
Iegnifen (Beni)
}

P. Morizot

\section{OpenEdition}

Journals

Édition électronique

URL : http://journals.openedition.org/encyclopedieberbere/1530

DOI : 10.4000/encyclopedieberbere. 1530

ISSN : 2262-7197

\section{Éditeur}

Peeters Publishers

\section{Édition imprimée}

Date de publication : 1 octobre 2001

Pagination : 3638-3639

ISBN : 2-7449-0207-1

ISSN : 1015-7344

Référence électronique

P. Morizot, «legnifen (Beni) », Encyclopédie berbère [En ligne], 24 | 2001, document I24, mis en ligne le

01 juin 2011, consulté le 25 septembre 2020. URL : http://journals.openedition.org/

encyclopedieberbere/1530; DOI : https://doi.org/10.4000/encyclopedieberbere.1530

Ce document a été généré automatiquement le 25 septembre 2020

(c) Tous droits réservés 


\section{Iegnifen (Beni)}

\section{P. Morizot}

1 Petite tribu berbère du Rif méridional, que Léon l'Africain localise entre les Beni Wuriaghel et les Beni Achmed et qui a donné son nom à la montagne qu'elle occupe.

2 Iegnifen se dit aussi Jenfan, transcription qui évoque le nom de Guenfan, père du chef maure Antalas qui joue un rôle prépondérant lors des révoltes berbères que rapporte Corippe dans la Johannide.

\section{BIBLIOGRAPHIE}

\section{Antiques :}

CORIPPE, La Johannide, Monumenta Germaniae historica, auctores antiquissimi, 3, 2.

Modernes :

LÉON L'AFRICAIN, Description de l'Afrique, traduit de l'italien par A. Épaulard, 1980.

INDEX

Mots-clés : Maroc, Tribu 